medRxiv preprint doi: https://doi.org/10.1101/2021.08.03.21261546; this version posted August 11, 2021. The copyright holder for this preprint (which was not certified by peer review) is the author/funder, who has granted medRxiv a license to display the preprint in It is made available under a CC-BY-ND 4.0 International license.

\title{
Title
}

\section{Cytogenetic \& Molecular analysis in Premature Ovarian Failure}

Chetan sahni ${ }^{1}$, Rima dada ${ }^{2}$

1. Institute of Medical Sciences, Banaras Hindu University, Varanasi, India

2. All India Institute of Medical Sciences, New Delhi, India

First Author: Dr. CHETAN SAHNI, Assistant Professor, IMS-BHU, chetansahni@bhu.ac.in

Corresponding Author: Dr. Rima Dada, Professor, AIIMS NEW DELHI,
rima_dada@rediffmail.com

\section{ABSTRACT:}

Introduction: Premature Ovarian Failure (POF) being a heterogeneous genetic disease involves the interaction of multiple genetic defects and environmental factors and has been associated with several chromosomal abnormalities, single gene mutations, and genetic polymorphisms. BMP15 is a member of the transforming growth factor $\beta$ (TGF- $\beta$ ) family. BMP15 gene product (protein) have 3 domians, mature domain (c-terminal region) of BMP15 binds to receptors located on granulosa cell surface to participate in key steps regarding ovarian function, such as granulosa cell proliferation and follicle maturation, ovulation rate modulation, oocyte competence determination and regulating granulosa cell sensitivity to FSH. Single nucleotide polymorphisms (SNPs) of the BMP-15 gene are associated with POF.

Materials \& Methods: 30 POF patients and 30 healthy age matched controls were recruited for cytogenetic and molecular analysis. $10 \mathrm{ml}$ whole blood was collected for karyotyping and PCR and PCR was performed for known SNPs of BMP-15 gene $(-9 \mathrm{C}>\mathrm{G}, 538 \mathrm{G}>\mathrm{A}$, 788insTCT and 852C $>\mathrm{T})$ respectively. Amplified PCR products were sequenced commercially.

Observation/Result: Thirty cases (mean age 30 years) and thirty healthy controls (mean age 23 years) were recruited for the study. On cytogenetic analysis 2 cases had a 45, XO chromosomal complement. One case was heterozygous for the SNP $(-9 \mathrm{C}>\mathrm{G})$ and one control was homozygous for the same SNP.

Discussion: The prevalence of this SNP was about $10.7 \%$ in cases \& $3.3 \%$ in healthy controls. This polymorphism in promoter region may cause altered expression of the gene and results in POF.

\section{INTRODUCTION}


medRxiv preprint doi: https://doi.org/10.1101/2021.08.03.21261546; this version posted August 11, 2021. The copyright holder for this

preprint (which was not certified by peer review) is the author/funder, who has granted medRxiv a license to display the preprint in It is made available under a CC-BY-ND 4.0 International license .

34 Premature ovarian failure (POF) refers to the development of amenorrhea due to cessation of

35 ovarian function before the age of 40 years and is characterized by low estrogen and elevated

36 serum gonadotropin. Elevated levels of Follicle Stimulating hormone (FSH) $(\geq 40 \mathrm{mIU} / \mathrm{ml})$

37 detected on at least two occasions a few weeks apart, is indicative of premature ovarian

38 failure. ${ }^{\mathbf{1 , 2}}$ The triad for the diagnosis of POF is amenorrhea, hypergonadotropism, and

39 hypoestrogenism. POF affects approximately $1 \%$ of the female population by age of 40 years

40 and $0.1 \%$ by age of 30 years worldwide. ${ }^{3}$ POF is not the same as natural menopause, as natural

41 menopause is an irreversible condition, while POF is characterized by intermittent ovarian

42 function in one half of young women. ${ }^{4}$

In the patients of POF, Hypoestrogenism can be satisfactorily treated by hormone

44 replacement therapy. In contrast, fertility cannot be recovered when the diagnosis of POF (or

45 end-stage POI- premature ovarian insufficiency) is generally reached and is often compromised

46 in the early phases of the disease when the clinical manifestations are absent. ${ }^{5}$ The age of onset

47 varies widely, depending on the age of onset, the disorder can manifest as primary amenorrhea,

48 without menarche, or secondary amenorrhea after the pubertal development. ${ }^{6}$

Kinch et al., (1965) found that there are two histopathological types of POF,

50 afollicular, and follicular form. In the afollicular form, there is a total depletion of ovarian

51 follicles with permanent loss of ovarian function. In the follicular form, follicular structures are

52 still preserved, hence a possibility of either spontaneous or induced return of ovarian function

53 exists. $^{7}$

\section{Causes of Ovarian Failure}


medRxiv preprint doi: https://doi.org/10.1101/2021.08.03.21261546; this version posted August 11, 2021. The copyright holder for this preprint (which was not certified by peer review) is the author/funder, who has granted medRxiv a license to display the preprint in It is made available under a CC-BY-ND 4.0 International license .

57 The causes of premature ovarian failure broadly categorized into the genetic and pathological

58 category. ${ }^{1}$ Amongst the genetic causes numerical \& structural anomalies of the $\mathrm{X}$ chromosome

59 adversely affect ovarian function. The most common form of $\mathrm{X}$ chromosome defect is Turner's

60 syndrome. Besides genetic causes, a wide spectrum of pathogenic mechanisms like autoimmune,

61 metabolic (galactosemia), infections (mumps), iatrogenic (anti-cancer treatment) may lead to the

62 development of POF. But, the Genetic causes of POF probably comprise about one-third to one-half

63 of all cases. $^{8}$

\section{Genetic Causes}

65 Chromosomal defects involving the X-chromosome are frequently seen in women with POF. The 66 deletion of $\mathrm{X}$ chromosome makes follicle or ovum unstable. ${ }^{1}$ In the majority of cases, $\mathrm{X}$ 67 chromosome defects cause deletion or disruption of genes located in the critical region of the $\mathrm{X}$ 68 chromosome between $\mathrm{Xq} 13$ and $\mathrm{Xq} 26$, which are critical for ovarian function. Several genes 69 responsible for oogenesis and normal ovarian functions are present on the $\mathrm{X}$ chromosome and 70 autosomes.

\section{Genes Involved}

72 Many genes on the X chromosome and autosomes regulate ovarian function. In a meta-analysis, D.

$73 \mathrm{Pu}$ et.al reported that five genes BMP15, ESR1, FMR1, FSHR, and INH are very important for

74 normal ovarian functions. They also found that single nucleotide polymorphisms and mutations in 75 these genes were found to be significantly more common in patients with POF compared with 76 controls. $9^{9}$ 
medRxiv preprint doi: https://doi.org/10.1101/2021.08.03.21261546; this version posted August 11, 2021. The copyright holder for this preprint (which was not certified by peer review) is the author/funder, who has granted medRxiv a license to display the preprint in It is made available under a CC-BY-ND 4.0 International license .

79 In our study, we had evaluated the polymorphism in the BMP15 gene, as the BMP15 gene has a very 80 important role in ovarian functions. The $B M P 15$ is a member of the transforming growth factor $\beta$ 81 (TGF- $\beta$ ) family, which is expressed by oocytes from the early stages of follicular maturation and 82 during all stages of development.10 BMP15 protein can form homodimers (BMP15: BMP15) or 83 heterodimers (BMP15: GDF9). The secreted soluble dimer binds to receptors located on the 84 granulosa cell surface to participate in key steps regarding ovarian function, such as granulosa cell 85 proliferation and follicle maturation, ovulation rate modulation, oocyte competence determination 86 and regulating granulosa cell sensitivity to FSH. ${ }^{11}$

87 In the Sanger sequencing projects of the BMP15 encoding region in panels of POF patients, more 88 than 15 missense variants were identified. ${ }^{\mathbf{1 2}}$ Most of them were located in the protein pro-region. 89 This scenario led to engage the researchers in a recent functional exploration of whether $B M P 15$ 90 promoter polymorphism might be related to the POF phenotype. It has been also established that this 91 variant modifies the paired-like homeodomain transcription factor 1 (PITX1) binding site and leads 92 to $B M P 15$ promoter transactivation disturbances. ${ }^{13}$ This might suggest that fine-tuning of $B M P 15$ 93 expression is critical for normal human ovarian physiology. BMP15 gene located on the short arm of the $\mathrm{X}$ chromosome $(\mathrm{Xp11.2)}$ within a 'POF 95 critical region'. ${ }^{14}$ BMP15 gene has two exons of 328 bp and $851 \mathrm{bp}$. In humans, mutations in the BMP15 gene have been found in association with both primary amenorrhea and secondary amenorrhea in several worldwide POF cohorts with a variable prevalence between 1.5 and $12 \% .^{5}$ 
medRxiv preprint doi: https://doi.org/10.1101/2021.08.03.21261546; this version posted August 11, 2021. The copyright holder for this preprint (which was not certified by peer review) is the author/funder, who has granted medRxiv a license to display the preprint in It is made available under a CC-BY-ND 4.0 International license.

In light of these findings, one could hypothesize that BMP15 variations might play a predisposing role in POF. The functional mechanism by which $B M P 15$ variants with a proven biological impact may disturb ovarian folliculogenesis is presently unknown. It may be predicted that a diminished BMP15 paracrine signal in the follicle would involve an impairment of the anti-apoptotic effects on granulosa cells. ${ }^{5}$ Indeed, further studies are needed to understand the exact role of BMP15 variants in POF pathogenesis. Thus in our study, we have evaluated the cytogenetic and molecular basis (mutation in $B M P 15$ ) of disease in cases of premature ovarian failure.

(1)

(1)

\section{Materials and Methods}

The study population consisted of 30 females of POF with no identifiable etiology after detailed clinical, gynecological evaluation. The control group included 30 healthy females with normal menstrual and fertility history. The relevant information regarding physical examination, clinical investigations, developmental milestones, occupational or environmental exposure to heat, radiation, chemicals, or toxins, were documented in a pre-designed proforma. Written informed consent was taken from each patient and control. The study was approved by the Institute Ethical CommitteeA.I.I.M.S. New Delhi (ref-no. IESC/T-150/01.04.2015).

The Inclusion criteria for study (infertile) group were: only Cases of idiopathic POF with primary and secondary amenorrhea after detailed gynecological \& cytogenetic investigations, with no recent history of illness, fever or medication (in past three months). 
medRxiv preprint doi: https://doi.org/10.1101/2021.08.03.21261546; this version posted August 11, 2021. The copyright holder for this preprint (which was not certified by peer review) is the author/funder, who has granted medRxiv a license to display the preprint in It is made available under a CC-BY-ND 4.0 International license.

The Inclusion criteria for Controls (fertile) group were: Controls who had normal menstrual and fertility history, with no recent history of illness, fever, or medication (in the past three months).

The Exclusion criteria for the study group and control group: 1) Gross dysmorphic abnormalities, structural defects, and systemic infection of the urogenital/reproductive system. 2) History of surgical intervention or trauma of genital/reproductive tract obstruction. 3) History of miscarriage, abortion whether spontaneous or induced. 4) Syndromic cases as Turner and Klinefelter (on cytogenetic evaluation).

For this case-control study, 30 cases of mean age $23 \pm 4.15$ years were recruited from the Department of Obstetrics \& Gynecology, AIIMS, New Delhi, and 30 controls of mean age $25 \pm 3.49$ years were recruited from a group of healthy wives of cases with male factor infertility \& healthy female volunteers from AIIMS, New Delhi. Cases included in this study were presented with premature ovarian failure but on clinical examination, no obvious cause was determined in them and all cases were phenotypically normal. So these cases were found idiopathic and further cytogenetic (karyotyping) and molecular (PCR) analyses were needed in all these cases, While Controls were presented with normal menstrual and fertility history, so cytogenetic (karyotyping) analysis was not done in controls. Three genetic analyses were used to observe the result.

1. Cytogenetic (Karyotyping) analysis in Cases (infertile group)

2. Molecular (PCR) analysis in both Cases (infertile group) \& Controls (healthy fertile group)

\section{Cytogenetic analysis}


medRxiv preprint doi: https://doi.org/10.1101/2021.08.03.21261546; this version posted August 11, 2021. The copyright holder for this preprint (which was not certified by peer review) is the author/funder, who has granted medRxiv a license to display the preprint in It is made available under a CC-BY-ND 4.0 International license.

151 In all infertile cases, the chromosomal analysis was done to identify any numerical or structural

152 chromosomal aberration. The metaphases were captured under 100X (Olympus optical company,

153 Ltd., Tokyo, Japan). The captured metaphases were analyzed using image analysis software

154 Cytovision 3.7 provided by Applied Imaging (ZEISS microscope, Germany) and classified

155 according to ISCN 2005. At least 50 metaphases were analyzed and karyotyped for each individual.

In karyotyping, it was observed that two cases out of 30 presented with Turner's karyotype

158 (45, X0). Although, in these two cases Turner's karyotype $(45, \mathrm{X} 0)$ was observed but they were 159 phenotypically normal. (fig. 1) These two cases were excluded from the study as cytogenetically 160 normal, idiopathic cases were included in this study. The remaining 28 cases were cytogenetically 161 normal.

\section{Molecular (PCR) analysis}

SNPs of the BMP15 gene were observed by using molecular (PCR) analysis. This molecular analysis was done in 28 cases which were found clinically as well as cytogenetically normal but have the phenotype of premature ovarian failure and in 30 healthy fertile controls. Total Genomic DNA was extracted from peripheral blood. Blood samples were collected from cases and controls in EDTA vials only after informed consent. DNA was isolated from 58 (28 cases and 30 controls) samples. Genomic DNA was isolated from peripheral blood samples by miller's protocol of DNA isolation. DNA was quantified by using a Nanodrop spectrophotometer (Thermo Scientific Corp., USA). 
medRxiv preprint doi: https://doi.org/10.1101/2021.08.03.21261546; this version posted August 11, 2021. The copyright holder for this preprint (which was not certified by peer review) is the author/funder, who has granted medRxiv a license to display the preprint in It is made available under a CC-BY-ND 4.0 International license.

177 The nucleotide variations in the BMP15 gene were analyzed in cases $(\mathrm{n}=28)$ and controls $(\mathrm{n}=30)$. In

178 the analysis of the BMP15 gene, 2 exons (with reference to July 2009 assembly of ensemble.

179

180 Amplicons (amplified exons) were electrophoresed using $1.8 \%$ agarose gel. Amplified PCR

181 products were purified using gel/PCR DNA fragments extraction kit (Geneaid Biotech Ltd., Sijhih

182 City Taiwan. Cat no DF100). Purified PCR products were sent for sequencing at MCLAB

183 (Molecular Cloning Laboratories) South San Francisco, CA 94080, U.S.A.

184 (http://www.mclab.com/product.php?productid=19071). DNA sequences were analyzed against

185 BMP15 reference sequence ENST00000252677.3 using ClustalW2 (multiple sequence alignment

186 program for DNA available at http://www.ebi.ac.uk/Tools/clustalw2/index.html provided by

187 European Molecular Biology Laboratory (EMBL) - European Bioinformatics Institute (EBI).

\section{Statistical Analysis}

192 The data has been expressed as mean $\pm \mathrm{SD}$ and/or median (minimum, maximum) as per the

193 statistical conventions. Associations were investigated by the chi-square test or fisher's exact test.

194 SPSS 11.5 (Texas, USA) was used for statistical analysis. Univariate and multivariable logistic

195 regression was done to see the unadjusted and adjusted odds ratio with 95\%CI. All the p-values less 196 than 0.05 were taken as significant. 
medRxiv preprint doi: https://doi.org/10.1101/2021.08.03.21261546; this version posted August 11, 2021. The copyright holder for this preprint (which was not certified by peer review) is the author/funder, who has granted medRxiv a license to display the preprint in It is made available under a CC-BY-ND 4.0 International license.

202

203

204

205

206

207

208

209

210

211

212

\section{MOLECULAR ANALYSIS}

By using sequencing analysis software (Chromas pro-2.4), it was observed that, in 3 cases, polymorphism at rs3810682: g.50910775C >G Promoter region of exon -1 of the BMP15 gene was present. Of the 3 in one case, it was homozygous change while in 2 cases, the heterozygous change was observed. (fig.2)

Out of 3 in one case, it was homozygous change. The frequency of the homozygous allele SNPs in cases was $3.7 \%$. In other 2 cases, the heterozygous change was observed. The frequency of the heterozygous allele SNPs in cases was 7\%. Besides cases, in one control heterozygous polymorphism was also observed. The frequency of heterozygous allele SNPs in control was 3.3\% and frequency of the homozygous allele SNPs in control was 0\%. (Table no. 2) All these changes were present at the same location (Promoter region of exon -1 of the BMP15 gene).

(1)

(1)

Fisher's exact test was used to analyze the frequency of SNP variant. It has been found the prevalence of BMP-15 SNP (rs3810682: g.50910775C >G) among cases was $10.7 \%$ and in controls $3.3 \%$. Although, P-value observed 0.344 (at 95\% significance level), which was not significant but prevalence was more in cases as compared to controls. (Table no. 3)

\section{$\underline{\text { Discussion }}$}

222 The possible involvement of BMP15 in POF pathogenesis was supported by evidence in animal

223 models. ${ }^{15}$ Di pasquale et.al, 2004 reported the first mutation of the BMP15 gene in two sisters with

224 ovarian dysgenesis. They also described the significant association of heterozygous BMP15 gene

225 variants with the POF phenotype in humans (seven of 166 patients: $4.2 \% ; P-0.003$ vs. controls).

226 These findings are consistent with the critical role played by BMP15 in human folliculogenesis. ${ }^{\mathbf{1 6}}$ 
medRxiv preprint doi: https://doi.org/10.1101/2021.08.03.21261546; this version posted August 11, 2021. The copyright holder for this preprint (which was not certified by peer review) is the author/funder, who has granted medRxiv a license to display the preprint in It is made available under a CC-BY-ND 4.0 International license .

Fonesca et al., 2014, were taken an in-silico approach, which identified that the PITX1

229 (pituitary homeobox 1 protein) factor binds to a sequence located between -14 to -8 of the $B M P 15$

230 promoter. It was shown that PITXI and BMP15 are co-expressed in both human adult oocytes and in

231 adult mouse ovaries. Functional in-vitro experiments showed that both $B M P 15$ promoter constructs (BMP15- prom-G and BMP15-prom-C) were activated by PITX1. A statistically significant 1.6 fold

increase in $B M P 15$ transcription activity conferred by the $B M P 15$-prom-G construct was found. This POF molecular etiology. ${ }^{\mathbf{1 3}}$ alterations among the POF populations. It was observed that both heterozygous and homozygous SNPs (BMP15 GENE Promoter region: $-9 \mathrm{C}>\mathrm{G}$ rs3810682: g.50910775C $>\mathrm{G}$ ) distribution in cases and controls) were present in 3 cases among 28 cases and in one control was observed. The prevalence was higher in cases as compared to controls. By using fisher exact t-test, we observed that although prevalence was higher in cases but p-value was 0.34 , which was not significant at $95 \%$

CI. This might be due to small sample size. In present study also observed that heterozygous SNPs

247 were more than Homozygous SNPs. Out of 3 in one case, it was homozygous change. The frequency

248 of homozygous allele SNPs in cases was 3.7\%. In other 2 cases, the heterozygous change was 249 observed. The frequency of heterozygous allele SNPs in cases was 7\%. Besides cases, in one control 250 heterozygous polymorphism was also observed. The frequency of heterozygous allele SNPs in 251 control was 3.3\% and frequency of homozygous allele SNPs in control was 0\%. All these changes 252 were present at the same location (Promoter region of exon -1 of the BMP15 gene). Two cases 
medRxiv preprint doi: https://doi.org/10.1101/2021.08.03.21261546; this version posted August 11, 2021. The copyright holder for this preprint (which was not certified by peer review) is the author/funder, who has granted medRxiv a license to display the preprint in It is made available under a CC-BY-ND 4.0 International license. presented with secondary amenorrhea and one with primary amenorrhea. So it suggesting that SNPs associated with $B M P-15$ gene cause both primary and secondary amenorrhea.

In previous literature, it has been observed that there is a strong correlation between mutation or SNPs of $B M P-15$ gene and premature ovarian failure as the $B M P-15$ gene is a regulator of important actions of granulosa cells of the ovary.

In the present study, it was observed that both heterozygous and homozygous SNPs were present in 3 of 28 cases and in one control heterozygous SNPs was observed. The prevalence was higher in cases as compared to controls. By using fisher exact t-test, we observed that although prevalence was higher in cases but p-value was 0.34 , which was not significant at $95 \%$ CI. This insignificance was due to recruitment of few cases, who presented with idiopathic POF which have normal (46, XX) karyotype. In present study also observed that heterozygous SNPs were more than Homozygous SNPs. Two cases presented with secondary amenorrhea and one with primary

amenorrhea. So it suggesting that SNPs associated with BMP-15 gene cause both primary and secondary amenorrhea

Further study, needed with a large cohort of idiopathic cases of premature ovarian

274 failure, to determine the prevalence of allele frequency observed during the study and its genotypephenotype correlation among both the primary \& secondary ovarian failure patients in Indian 
medRxiv preprint doi: https://doi.org/10.1101/2021.08.03.21261546; this version posted August 11, 2021. The copyright holder for this preprint (which was not certified by peer review) is the author/funder, who has granted medRxiv a license to display the preprint in It is made available under a CC-BY-ND 4.0 International license.

population and expand mutation spectrum.

DISCLOSURE: conflict of interest- "None"

\section{BIBLIOGRAPHY}

1. Conway GS, Kaltsas G, Patel A, Davies MC, Jacobs HS. Characterization of idiopathic premature ovarian failure. Fertil Steril. 1996; 64:337-41.

2. Goswami D, Conway GS. Premature ovarian failure. Hum Reprod Update. 2005 Jul-Aug; 11(4):391-410.

3. Coulam CB, Adamson SC, Annegers JF: Incidence of premature ovarian failure. Obstet Gynecol 67:604-606, 1986.

4. Nelson LM, Anasti JN, Kimzey LM, Defensor RA, Lipetz KJ, White BJ, Shawker TH,

Merino MJ. Development of luteinized graafian follicles in patients with karyotypically normal spontaneous premature ovarian failure. J Clin Endocrinol Metab. 1994 Nov; 79(5):1470-5.

5. Persani L, R. Rossetti, C. Cacciatore Genes involved in human premature ovarian failure J.

6. Timmreck LS, R.H. Reindollar Contemporary issues in primary amenorrhea Obstet. 
medRxiv preprint doi: https://doi.org/10.1101/2021.08.03.21261546; this version posted August 11, 2021. The copyright holder for this preprint (which was not certified by peer review) is the author/funder, who has granted medRxiv a license to display the preprint in It is made available under a CC-BY-ND 4.0 International license .

7. $\quad$ Kinch R, Plunkett E, Smout M, Carr D. Primary Ovarian Failure; A Clinicopathological

And Cytogenetic Study. Am J Obstet Gynecol. 1965 Mar 1; 91:630-44.

8. $\quad$ Kumar M, Pathak D, Venkatesh S, Kriplani A, Ammini AC, Dada R. Chromosomal

abnormalities \& oxidative stress in women with premature ovarian failure (POF). The Indian

Journal of Medical Research. 2012; 135(1):92-97.

9. $\mathrm{Pu} \mathrm{D}$, Xing Y, Gao Y, Gu L, Wu J. Gene variation and premature ovarian failure: a metaanalysis. Eur J Obstet Gynecol Reprod Biol. 2014 Nov; 182:226-37

10. Dube JL, Wang P, Elvin J, Lyons KM, Celeste AJ, Matzuk MM. The bone morphogenetic protein 15 gene is X-linked and expressed in oocytes. Mol Endocrinol. 1998 Dec; 12(12):1809-17.

11. Hanrahan JP, Gregan SM, Mulsant P, Mullen M, Davis GH, Powell R, Galloway SM.

Mutations in the genes for oocyte-derived growth factors GDF9 and BMP15 are associated with both increased ovulation rate and sterility in Cambridge and Belclare sheep (Ovis aries). Biol Reprod. 2004 Apr; 70(4):900-9 Hum. Reprod. Update, 20 (2014), pp. 869-883 
medRxiv preprint doi: https://doi.org/10.1101/2021.08.03.21261546; this version posted August 11, 2021. The copyright holder for this preprint (which was not certified by peer review) is the author/funder, who has granted medRxiv a license to display the preprint in It is made available under a CC-BY-ND 4.0 International license.

may contribute to the cause of non-syndromic premature ovarian failure. Reprod Biomed Online. 2014 Nov; 29(5):627-33.

14. Zinn AR, Tonk VS, Chen Z, Flejter WL, Gardner HA, Guerra R, Kushner H, Schwartz S,

Sybert VP, Van Dyke DL, Ross JL. Evidence for a Turner syndrome locus or loci at Xp11.2-p22.1.

Am J Hum Genet. 1998 Dec; 63(6):1757-66.

15. Galloway SM, McNatty KP, Cambridge LM, Laitinen MP, Juengel JL, Jokiranta TS,

McLaren RJ, Luiro K, Dodds KG, Montgomery GW, Beattie AE, Davis GH, Ritvos O. Mutations in an oocyte-derived growth factor gene (BMP15) cause increased ovulation rate and infertility in a dosage-sensitive manner. Nat Genet. 2000 Jul; 25(3):279-83.

16. Di Pasquale E, Beck-Peccoz P, Persani L. Hypergonadotropic Ovarian Failure Associated with an Inherited Mutation of Human Bone Morphogenetic Protein-15 (BMP15) Gene. American Journal of Human Genetics. 2004; 75(1):106-111. rate in sheep. Genet Sel Evol. 2005; 37 Suppl 1:S25-38. 
$\begin{array}{ll}1 & 4 \\ 2 & 4 \\ 2 & 4 \\ 5 & 4\end{array}$

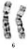

s

T⿰冫.

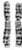

2
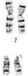

14

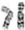

E.

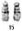

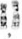

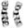

11

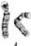

4

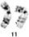

$\begin{array}{cc}4 & 9 \\ 2 & 0\end{array}$

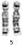

5

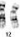

11

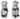

1)
$9-88$
1
2

- -

ㄱ. 을

H.

21

ร 
Reference

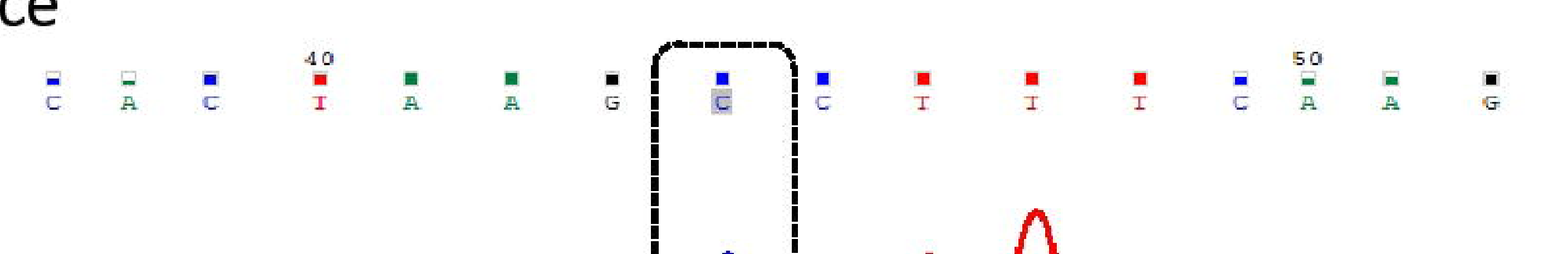

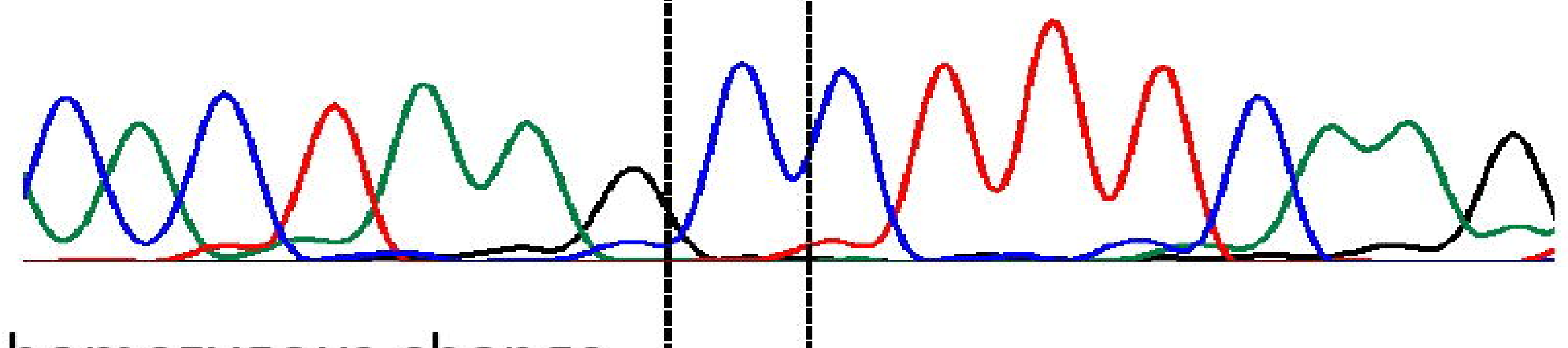

Patient homozygous change

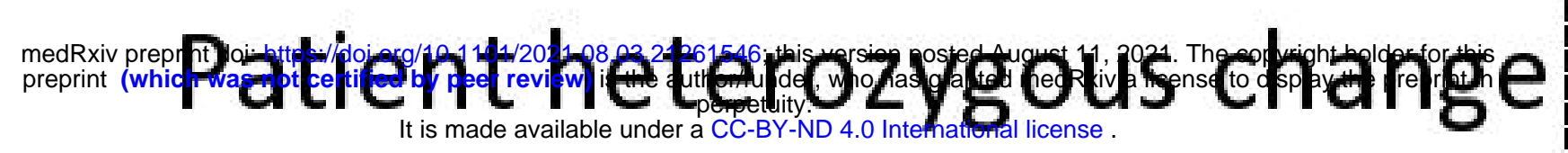

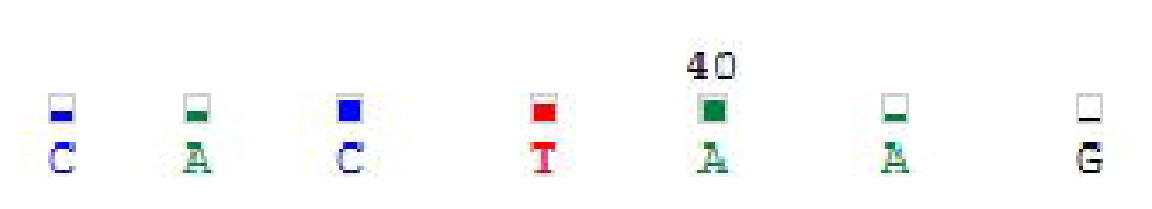

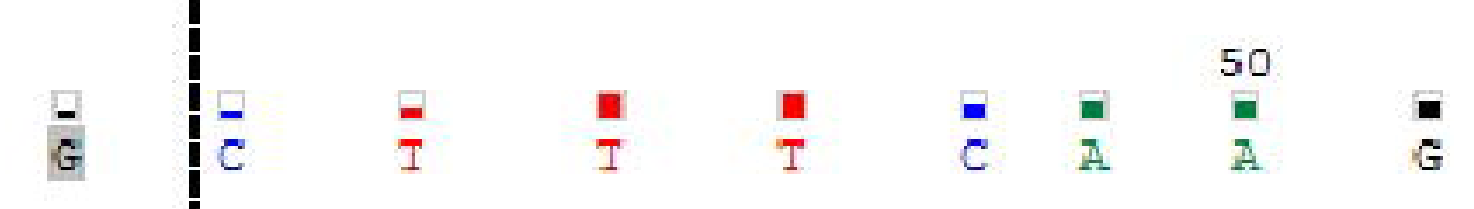

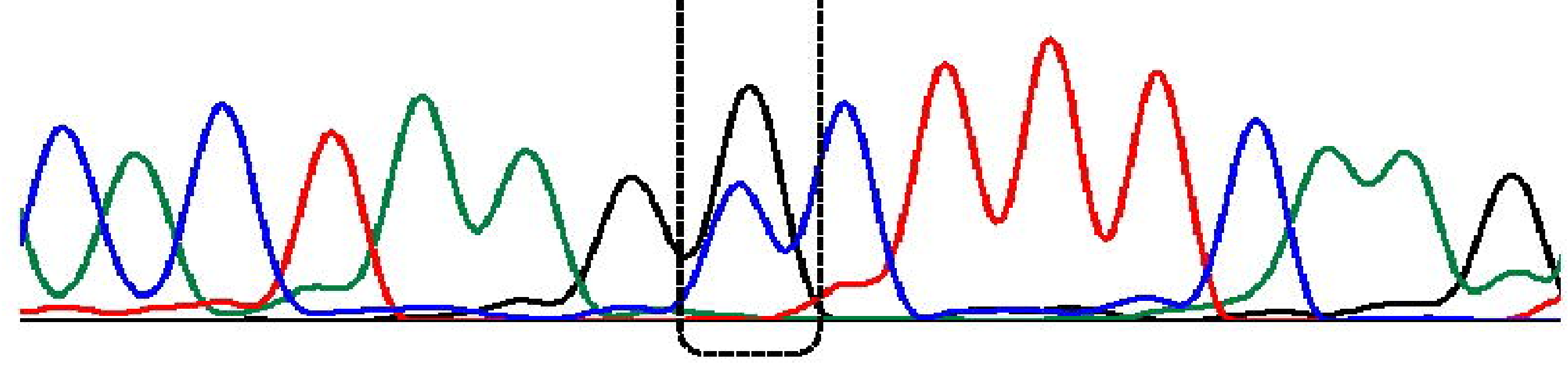

Fig. 2: Chromatogram showing sequencing results 


\begin{tabular}{|c|l|}
\hline \multicolumn{2}{|c|}{ Designed primers: for 2 exons of BMP15 gene. } \\
\hline Exon 1 & $\begin{array}{l}\text { Forward-GGA GCC AGG ATG CAG TTA TCT GC } \\
\text { Reverse -CAG GGC AGT ATG GGG GCA TAA C }\end{array}$ \\
\hline Exon 2 & $\begin{array}{l}\text { Forward-GGT TCT GGA ATA ACA AGG GAC } \\
\text { Reverse-CTC TCC TCC AGT TTC CTG G }\end{array}$ \\
\hline \hline
\end{tabular}

Table no. 1: Primers for Exon-1 \& Exon-2 of BMP15 gene 


\begin{tabular}{|c|c|c|c|c|c|c|}
\hline & \multicolumn{2}{|c|}{ CASES } & \multicolumn{2}{|c|}{ CONTROL } & \multicolumn{2}{|c|}{ TOTAL } \\
\hline Allele & $\mathrm{N}$ & $\%$ & $\mathrm{~N}$ & $\%$ & $\mathrm{~N}$ & $\%$ \\
\hline $\begin{array}{l}\text { Heterozygous } \\
\text { (C/G) }\end{array}$ & 2 & $7 \%$ & 1 & $3.3 \%$ & 3 & $5.2 \%$ \\
\hline $\begin{array}{l}\text { Homozygous } \\
\text { (G/G) }\end{array}$ & 1 & $3.7 \%$ & 0 & $0 \%$ & 1 & $1.7 \%$ \\
\hline $\begin{array}{c}\text { Homozygous } \\
\text { (Reference-Normal) } \\
\text { (C/C) }\end{array}$ & 25 & $89.3 \%$ & 29 & $96.3 \%$ & 54 & $93.1 \%$ \\
\hline Total & 28 & $\%$ & 30 & $100 \%$ & 58 & $100 \%$ \\
\hline
\end{tabular}

Table no. 2: Allele frequency of SNPs among Cases \& Controls 


\begin{tabular}{|c|c|c|c|}
\hline Group & $\begin{array}{c}\text { BMP15 reference gene } \\
\text { (CC-Wild type) }\end{array}$ & $\begin{array}{c}\text { BMP15 variant }(C G / G G) H O M O / \\
\text { HETEROZYGOUS VARIANT }\end{array}$ & \\
\hline Cases & $25(89.3 \%)$ & $3(10.7 \%)$ & $28(100 \%)$ \\
\hline Controls & $29(96.7 \%)$ & $1(3.3 \%)$ & $30(100 \%)$ \\
\hline Total & $54(93.1 \%)$ & $4(6.9 \%)$ & $58(100 \%)$ \\
\hline
\end{tabular}

Table no. 3: BMP15 GENE (Rs3810682: g.50910775C>G) SNPs distribution in cases and controls 